\title{
Multilateralism, but not as we know it: Anglo-American economic diplomacy in South America during World War II
}

Thomas C. Mills

Department of Politics, Philosophy and Religion, Lancaster University, Lancaster, UK

\begin{abstract}
This article explores economic diplomacy between the United States and Great Britain in South America during the Second World War. The dominant theme presented in the existing relevant literature on this subject is one whereby the US promoted a multilateral economic system, based on equal access to markets and resources, against the opposition of a British government determined to protect a closed trading system. The situation that arose in South America was markedly different. It was Britain that promoted multilateralism in South America, based on the belief that such a system would provide the surest means of protecting its interests in this region. The US, on the other hand, prioritised security concerns and shortterm economic gains over the promotion of a multilateral trading system in its policy towards South America. In exploring this alternative situation that arose in South America this article represents a challenge to traditional conceptions of Anglo-American economic diplomacy during World War II.
\end{abstract}

Keywords: Anglo-American relationship, South America, post-war planning, economic diplomacy, multilateralism

Amidst the joint military operations, intelligence cooperation, diplomatic exchanges and close personal relationships that constituted the Anglo-American alliance of the Second World War, the United States and Great Britain also sought to reach agreement over the nature of the global economic system that would take shape once the war was over. The Great Depression of the 1930s had crippled the global economy, with world trade shrinking to a third of its 1928 level by the summer of 1932 and recovering only haltingly in subsequent years. ${ }^{1}$ The outbreak of world war in the 1940s wholly dislocated the norms of international trade and finance and left uncertain the politico-economic structures that would be left in its wake.

In this sense the war also represented something of an opportunity for the United States - as the pre-eminent rising international power of the time - to shape the political economy of the post-war world. ${ }^{2}$ In seeking to do this diplomacy with Britain during the war was of paramount importance. Although by this time a declining power, London was still the centre of the financial world and British traders retained a firm grip on large amounts of international trade by the early 1940s. The Anglo-American wartime alliance was thus the principal forum in which post-war economic diplomacy took place. This took the form of high-level negotiations concerning the economic governance structures to be instituted in the post-war years. Similarly, there was ongoing localised rivalry between private interests and official representatives of the two nations in regions anticipated to be of particular significance to the future commercial prospects of either country.

One such region that fell within this latter category was South America. Throughout the nineteenth century Britain dominated South American commerce, securing important export markets, establishing itself as the chief customer for many of the region's primary raw materials and investing heavily in public utilities like telecommunications and railways. ${ }^{3}$ By the turn of the twentieth century British domination of South America was increasingly challenged by the US, as the country made significant commercial inroads in Brazil and established important strategic interests in the region. ${ }^{4}$ The US increased its presence in 
South America during the First World War, exploiting opportunities created by the conflict to replace European exports to the region with its own. ${ }^{5}$ Moreover, in the decade that followed, US private interests, with the backing of their government, successfully challenged Britain's predominance in banking and capital investment in the region. ${ }^{6}$ The tide continued to turn in favour of the US in the depression-laden 1930s, as inter-American trade was consolidated in order to make up for the loss of European markets, whereas Britain sacrificed much of its presence in South America in favour of Empire trade. ${ }^{7}$

Thus, by the outbreak of the Second World War the US had replaced Britain as the dominant foreign economic power in South America. Nevertheless, Britain still retained substantial interests in the region, particularly in Argentina. South America remained, therefore, of substantial commercial interest to both the US and Britain by the outbreak of World War II. Moreover, as this article will demonstrate, the economic diplomacy that transpired between the two powers concerning South America differed markedly from that regarding other parts of the world and in more general negotiations. As such, this article makes the case that exploring the situation that unfolded in South America makes a valuable contribution to broader debates on Anglo-American economic diplomacy during the Second World War.

\section{The historiography of Anglo-American economic diplomacy}

Just as he had dominated much of the war itself, the early literature on the Anglo-American wartime alliance was written in the shadow of Winston Churchill's six volume history of the conflict, published in the late 1940s and early 1950 s. $^{8}$ Conscious to avoid publication of anything that could damage the Anglo-American 'special relationship' that he had laboured so hard to construct during the war, Churchill intentionally omitted issues from his history which had in fact caused tensions and rivalries between the two countries. ${ }^{9}$ Contentious issues such as economic diplomacy were therefore largely absent from Churchill's work and the studies written in its wake. ${ }^{10}$

This silence was only broken in 1956 with the publication of Richard Gardner's study of Anglo-American negotiations concerning the post-war global economy, Sterling-Dollar Diplomacy. At the centre of Gardner's book was the attempt to implement a multilateral trading system for the post-war era. Based on the principles of equality of access to the world's markets and raw materials, free convertibility of currency and a general stabilisation of exchange rates, the ambition was that this system would replace the protectionist structures developed by nations during the inter-war period. ${ }^{11}$ Foremost among these was the imperial preference system and sterling area operated throughout the British Empire. Created at the Ottawa conference of 1932, imperial preference granted preferential tariffs for countries within the British Empire and therefore discriminated against outside countries, such as the United States. ${ }^{12}$ Similarly, the sterling area pegged the currencies of Empire countries to the pound and tied up their export earnings in sterling loans lodged in London. ${ }^{13}$ Proclaimed as an Anglo-American war aim in the Atlantic Charter of 1941, reaffirmed in the Master LendLease agreement of the following year and ratified in the Bretton Woods agreements of 1944, the attempt to institute a multilateral trade system was indeed the dominant feature of AngloAmerican economic diplomacy during the war. ${ }^{14}$

The motivation behind multilateralism, according to its chief advocate, US Secretary of State Cordell Hull, went way beyond the realm of commerce. Rather, Hull and his internationalist followers in the State Department believed that the barriers to international trade erected in the past had laid the foundations for political rivalries, resulting eventually in war. Once these trade barriers were removed, Hull believed, commercial interactions between nations would increase, resulting in friendly political relations. Moreover, Hull 
believed that the freer trade achieved by nations in a multilateral system would lead to greater prosperity for all. Such prosperity, so the argument went, would eliminate the need for nations to embark upon the kind of economic warfare that eventually led to the use of force. Thus, economic planning for the post-war world was being put to the service of a broader scheme to secure lasting peace and stability on a worldwide basis. ${ }^{15}$

But while Gardner's book certainly broke new ground by introducing economic diplomacy to the historiography of Anglo-American relations during World War II, it simultaneously reinforced Churchill's image of amity between the two nations by depicting efforts to construct a multilateral system for the post-war era as a collaborative effort serving the interests of both countries. This characterisation was only challenged with the emergence of revisionist scholars in the 1960s.

In the first major revisionist work, The Tragedy of American Diplomacy, William Appleman Williams fully accepted that the central aim of US economic diplomacy in the Second World War was to institute a multilateral system that would facilitate greater access to markets and resources. But, Williams crucially pointed out that such a system would, by way of the country's anticipated economic superiority by the end of the Second World War, principally act to guarantee US access above that of all others. Williams' central thesis was that US business and political leaders in the twentieth century came to believe that an essential prerequisite for the country's economic and political well-being was a need to continually expand foreign markets. Instituting a multilateral global trading system for the post-World War II era would achieve this goal by ensuring an 'open door' for US economic expansion. ${ }^{16}$ In the revisionist thesis, then, it was US domestic prosperity, rather than a desire to create the economic conditions necessary for world peace, that constituted the principal motivation behind the attempt to institute multilateralism in the Second World War.

Heavily influenced by Williams, Gabriel Kolko applied much the same open door thesis to his 1968 study of wartime diplomacy, The Politics of War. ${ }^{17}$ Lloyd C. Gardner adopted a similar thesis in his analysis of the Roosevelt administration, Economic Aspects of New Deal Diplomacy. ${ }^{18}$ In these works the general paradigm presented was one whereby the US economic system's need for post-war markets and resources compelled the Roosevelt administration to employ multilateralism as a lever with which to prize open Britain's imperial preference system. Recognising the selfish motivations driving US policy, Britain baulked at this effort and tried to preserve the markets ensured under imperial preference and the sterling area, which the Churchill government believed would be so vital to the country in the post-war era. ${ }^{19}$

This portrayal of Anglo-American rivalry over economic policy was further developed in the 1970s and 1980s in a number of works which benefited from the declassification of wartime documents that revealed a relationship that was generally much more competitive than had previously been represented. ${ }^{20}$ But while economic rivalry had by this time been firmly established as an integral component of the historiography of AngloAmerican relations during the war, the nature of that rivalry - whereby the US advocated multilateralism against British opposition - remained largely unquestioned.

This changed with the publication in the late 1980s and early 1990s of works from both sides of the Atlantic which re-examined Anglo-American economic diplomacy. Randall B. Woods' study, A Changing of the Guard, explored the inter-agency rivalry within the Roosevelt administration for control over economic policy. While internationalists in the State Department and White House advocated multilateralism, a combination of bureaucratic imperialists within the Treasury, supported by Congressional conservatives serving special interests, wished to commit the country to a programme of economic nationalism. The result, Woods argued, was the advocacy by the Roosevelt administration of a 'modified multilateralism', which sought the more limited goals of transferring financial power from 
London to Washington and boosting US exports. ${ }^{21}$ Similarly, Alan Dobson's study, US Wartime Aid to Britain, demonstrated that Britain's ability to compete in a multilateral system in the post-war era was constrained by the US Treasury's wartime policy of limiting British reserves. Moreover, British officials were concerned over the timing of the reforms to the global economy being proposed by their US counterparts. While the majority of British officials may have agreed with the policy of multilateralism, therefore, they disagreed with the US strategy of how to achieve such a goal. ${ }^{22}$

But notwithstanding the important contributions of these studies, the dominant trend in the literature on Anglo-American economic diplomacy during the Second World War remains to emphasise the US commitment to multilateralism, alongside British resistance to this policy. ${ }^{23}$ This pattern is reinforced in the various works exploring Anglo-American rivalry concerning particular regions. The vast majority of these have focused on areas such as Southeast Asia, the Middle East and North Africa, which had traditionally been dominated by Britain - both through its official and 'informal empire' - and where the US previously lacked a substantial presence. ${ }^{24}$ In these regions it was only natural that diplomacy between the two countries would reflect the pattern of general negotiations, whereby the US promoted a multilateral system against British opposition.

\section{South America in the existing literature}

Similar studies of Anglo-American economic diplomacy concerning South America have, until recently, been studiously avoided. ${ }^{25}$ For some, this omission is a wholly correct reflection of the significance of the topic. One of the few occasions that Anglo-American relations in South America has been discussed at any length is in a collection of essays exploring the role of Argentina in international politics during the Second World War years. This collection includes contributions by Alec Campbell and Warren Kimball, offering, respectively, a British and American perspective on the relationship between the wartime allies in Latin America. ${ }^{26}$ The unanimous conclusion reached in these pieces is that AngloAmerican relations in the region amounted to little of interest to historians.

On the one hand, this argument is based upon the claim that officials in Washington and London did not pay enough attention to Latin America during the war to warrant historical enquiry into the topic. But this conclusion is reached largely on the basis of the lack of reference to the region by Roosevelt and Churchill. While it is certainly true that the wartime leaders did not pay significant attention to Latin America during the war, to disregard the significance of the region on this basis seems unwise. In the case of Roosevelt, issues concerning Latin America were largely delegated to his trusted and influential friend Sumner Welles, the US Under Secretary of State. ${ }^{27}$ More broadly, neither Roosevelt nor Churchill had much interest in any matters during the war other than those directly related to the prosecution of the conflict. ${ }^{28}$ And while this was surely a sensible prioritisation of topics at the time, it certainly does not mean that the whole panoply of issues in Anglo-American relations considered at governmental levels below that of the executive was insignificant particularly when these issues were part of broader changes in the international balance of power, as economic diplomacy between the two powers was.

The second basis upon which Anglo-American relations in Latin America is discounted in these essays is on the grounds that there was sufficient acceptance among British officials that Latin America fell within Washington's sphere of influence, and that this in turn prevented any real rivalry between the powers from taking place in the region. It is certainly true that British officials recognised the US as the predominant external political influence in South America by the time of the Second World War. But equally, there was a widespread determination throughout the British government to retain and, indeed, expand its 
commercial interests in South America in the post-war era. ${ }^{29}$ As this article will go on to show, this determination led to continuous rivalry between the two powers throughout South America, and, moreover, high-level negotiations concerning the fate of British interests in the region in the broader context of Anglo-American relations.

\section{Anglo-American economic diplomacy in South America}

The negotiations between the US and Britain concerning South America differed markedly from those regarding other parts of the world and the more general diplomacy concerning the economic shape of the post-war world. It was Britain that promoted multilateralism in its diplomacy with the US concerning South America. Britain lacked the preferential position in South America that it sought to defend in other parts of the world. A multilateral system based on equality of access to markets and raw materials therefore represented its best chance of holding on to its commercial interests in the region. The Roosevelt administration, on the other hand, was divided concerning the appropriate attitude to be taken towards Britain in diplomacy concerning South America. On the one hand there were those like the internationalists in the State Department who wished to promote multilateralism in South America in the service of bringing about such a system on a global scale in the post-war era. Others, however, like the State Department's Latin Americanists and influential temporary government agencies, pursued policies that had the effect of excluding British interests from South America, and thereby denying Britain the export markets required for the country to participate in a multilateral system in the post-war era.

Even prior to the US entry into the war in December 1941, groups within the country intent upon excluding British interests from South America factored in Anglo-American diplomacy concerning the region. From September 1939 onwards members of the US business community and sections of the Roosevelt administration instinctively hostile towards Britain rallied around criticisms of British trade practices in the region. Whether it related to British censorship in the Western Hemisphere, measures of economic warfare, or Britain's export policy towards the region, the recurring theme of this criticism was that Britain was following policies ostensibly aimed at advancing the Allied war effort that in fact harmed US commercial interests in South America, while advancing Britain's own. ${ }^{30}$ E. F. McDonald, a low-ranking official in the Roosevelt administration, spoke for many in the US when he expressed suspicion of British motives. 'Never for a minute', stated McDonald, 'no matter how dire the emergency, do the British fail to think of the ultimate future and their position'. 31

There was a keen desire within the British government to refute such claims. ${ }^{32}$

However, as criticisms of British trade practices in South America became an increasingly prominent political issue in the US they were consequently viewed in London as a threat to winning the Roosevelt administration's support for the British war effort. London therefore took a variety of steps to pacify criticisms of British commercial activities in South America. These included adjusting censorship arrangements, aligning London's blacklisting policies with Washington's and finally, in September 1941, issuing the Export White Paper forbidding Britain from using materials received from the US under the Lend-Lease aid programme 'in such a way as to enable their exporters to enter new markets or to extend their export trade at the expense of the United States'. ${ }^{33}$ Cumulatively, the effect of these measures was a contraction of British economic interests in South America, and in this sense an early success for those intent upon excluding British interests from the region. ${ }^{34}$

Following Pearl Harbor, and the subsequent conversion of the US to a full belligerent in the global conflict, relations between the allies in South America improved. More specifically, the two countries collaborated in blacklisting policy and took steps towards 
coordinating the supply of essential goods to the region. ${ }^{35}$ However, such cooperation as existed was restrained throughout the first half of 1942, as British attempts to forge a collaborative partnership between the two countries in South America were continually hindered by unilateralist tendencies in the US. As expressed in a State Department memo of April 1942, US joint policy with Britain towards South America should be premised on the basis that 'the Western Hemisphere is our back yard and we are the ones, like it or not, who are going to play a principal role there'. ${ }^{36}$ This kind of attitude fuelled suspicions among British officials and businessmen that the true aim of their US counterparts was indeed to use opportunities afforded by the war to exclude British commercial interests from South America on a permanent basis. ${ }^{37}$ As Victor Perowne, head of the South American department of the Foreign Office put it, there was a clear tendency within the US that was 'determined to eliminate all alien influences (including our own) in Latin America',38

Such anxieties on Britain's part were a cause for concern to the State Department's internationalists who feared that tensions between the two countries in South America could jeopardise efforts to win British cooperation in promoting a global multilateral trade system for the post-war era. ${ }^{39}$ This group therefore attempted to quell British fears by instructing US representatives in South America to promote multilateralism in all dealings with Britain in the region. As Dean Acheson put it in a telegram to US representatives throughout the region, 'the principle of non-discrimination and equality of treatment among nations', which had been negotiated as part of the Master Lend-Lease agreement, should serve as the basis for all commercial dealings with the British in Latin America. ${ }^{40}$ Such a message was vital, believed fellow internationalist Selden Chapin, if the Roosevelt administration were to convince Britain that the US did not look upon Latin America 'as a closed market for American goods'. ${ }^{41}$ These attempts at fostering cooperation between the wartime allies in Latin America began to bear fruit during the second half of 1942, as diplomats and businessmen from either country sought to put their differences aside in the name of the common war effort. ${ }^{42}$ Subsequently, there resulted in London a lessening of suspicions that the US was intent upon excluding British interests from the region. ${ }^{43}$

However, throughout the autumn of 1942 and into the spring of 1943 it became clear that, notwithstanding the efforts of the internationalists to promote multilateralism in Latin America, there remained powerful forces within the Roosevelt administration which posed a direct challenge to this goal. The most important of these was the State Department's Latin Americanists. Led by Sumner Welles, this group tended to take the lead in formulating policy towards the region and often did so without reference to broader geopolitical concerns. ${ }^{44}$ One of Welles' principal aims for the post-war era was to promote an enhanced inter-American security system in the Western Hemisphere. ${ }^{45}$ However, Welles feared that European control over important industries and export markets in Latin America could provide European powers with the ability to disrupt such a system. On the basis of this fear, Welles in January 1943 advised a British official that it was necessary for the US 'to build up a position both in the political and economic fields which would enable them to occlude any such ... activities'. Such a policy would necessarily require US commercial dominance of the region, to the exclusion of significant British interests. ${ }^{46}$

Similarly, temporary government agencies created for the wartime period, which often had close links to business in the US, sought to promote US commercial interests in South America. For example, Nelson Rockefeller's Office of the Coordinator for InterAmerican Affairs ensured the passing of tax legislation that gave US companies a preferential position in South America over their British competitors. ${ }^{47}$ In the same vein Eric Johnston, head of the Inter-American Development Commission, commented following a tour of Latin America in 1943 that whereas the last century in Latin America had been a 'British Century', the next would be an 'American Century'. ${ }^{48}$ 
Collectively, these groups represented a parochial faction within the US, focused on Latin America, and largely impervious to how this region related to broader global issues of post-war planning. While it may not always have been their intention, the policies pursued by these groups did in fact threaten to exclude British interests from South America. As British officials observed these tendencies, any optimism that the previous efforts of the Roosevelt administration's internationalists would protect British interests and engender cooperation between the two countries in Latin America soon evaporated. ${ }^{49}$

With British fears of the country's interests being excluded from South America firmly re-established by the spring of 1943, Whitehall departments embarked upon a lengthy reformulation of British policy towards Latin America. ${ }^{50}$ This took place against a backdrop of broader changes in the Anglo-American economic relationship, not least the advent of 'reverse Lend-Lease' - the process whereby Britain supplied goods to the US. ${ }^{51}$

Developments such as this, British ministers believed, allowed Britain to take a tougher stance in their negotiations with the US. In the case of reformulating policy towards Latin America this attitude found voice in a meeting of the War Cabinet Lord President's Committee on 21 May. Here, President of the Board of Trade Hugh Dalton and Foreign Secretary Anthony Eden presented a memorandum pointing to the 'urgent need of an approach to the United States Government . . . if this country is to stand any chance of regaining its Latin American markets after the war'. ${ }^{52}$ Subsequently, Lord Halifax, the British ambassador in Washington, met with Hull to discuss Anglo-American relations in Latin America in July of that year.

The aide-memoire handed to Hull on this occasion tactfully articulated British fears in Latin America, describing 'an impression, however false, that there may be some desire on the American side to supplant British traders in [their] established and traditional markets, not only for the war period, but permanently thereafter'. In order to counteract this notion Halifax asked Hull if the US government would agree to what the Foreign Office termed a 'self-denying ordinance' in Latin America - namely 'the principle that no advantage in world markets shall accrue to either country at the expense of the other by reason of sacrifices made in the interest of the effective prosecution of the war'.

Furthermore, in making its case to the Roosevelt administration, the British government framed its call for such restraint in the context of the multilateral trade programme, which had been continually advocated by the Roosevelt administration as the basis for the post-war economic order. Specifically, the aide-memoire set out the argument that continued British access to the markets of South America - which a self-denying ordinance would be essential in preserving - must be a constituent part of an economic world order based on equal access to markets and resources. Without access to such markets Britain would lack the necessary balance of payments to be able to participate in a multilateral system. By linking the protection of British markets to the country's ability to participate in the multilateral trade regime that the State Department's internationalists were so attached to, Britain made a request that this group's leader, Secretary of State Hull, could scarcely reject. He subsequently denied that there was any intention on the part of the US to purge British interests from Latin America and pledged agreement to the principle of a selfdenying ordinance. ${ }^{53}$

However, while Hull agreed to this principle in theory, the US government as a whole subsequently failed to adhere to it in practice. This failure was due to a number of factors, including the bureaucratic nature of the US government, a lack of leadership on Latin American policy following the departure of Sumner Welles in September 1943, and a growing disillusionment among US officials with Britain's activities in Latin America following disagreements over policy towards Argentina. ${ }^{54}$ But regardless of the reasons for the US failure to adhere to the self-denying ordinance pledged by Hull, the result was that 
policies and programmes which had the effect of excluding British interests from South America were largely allowed to continue. For example, when it came to implementing the Axis Replacement Programme in South America - whereby German and Italian concerns were eradicated from the region - there was little effort to prevent US companies from replacing them and thereby benefitting from wartime conditions. ${ }^{55}$ Similarly, in a case that had come to be seen as something of a litmus test for Anglo-American relations in South America, the Roosevelt administration failed to prevent a US company from gaining the contract for the electrification of the Central Brazilian railway, after it had been lost by a British firm due to supply shortages brought about by the war. ${ }^{56}$ Thus, the British attempt to institute a self-denying ordinance in Latin America - and thereby increase the likelihood of successfully implementing of a multilateral economic system for the post-war era - ultimately proved to be a fruitless one.

\section{Conclusion}

The fact that the British approach to the State Department concerning Latin America was considered at the highest levels of government in London, and, moreover, that the substance of the policy to be presented to the US had been the subject of so much debate between Whitehall departments over the previous months, demonstrates the error of previous studies in claiming that the region was of little or no importance to Britain, and therefore inconsequential to Anglo-American relations during the war. In particular, the foregoing offers a comprehensive rebuttal of Alec Campbell's claim that the British government had 'little disposition to try [to moderate US] policy in the Western Hemisphere'. ${ }^{7}$ More broadly, the rivalry that took place between the two nations in this region throughout the war has the effect of locating in South America, a further significant arena of rivalry between the US and Britain during the Second World War.

The nature of the rivalry between the two nations in South America also means that research in this area can contribute to broader debates concerning Anglo-American economic diplomacy during the Second World War. While the dominant trend in the literature remains to emphasise the US championing of multilateralism against British opposition, the situation that arose in South America was very different. In this region it was Britain that emerged as the primary advocate of multilateralism and the US which, following internal struggles between different factions, failed to effectively promote a liberal trade agenda. This demonstrates that Britain was by no means opposed in principle to the implementation of a multilateral trading system for the post-war era. On the contrary, the British government wished to see such a system take shape, but equally recognised that for this to happen would require the US - as the emergent leading economic power in the world - to take active steps towards achieving this goal, such as ensuring that South American markets remained open to major trading nations like Britain in the post-war years.

The fact that the US proved inadequate to this task is indicative of the limitations of the Roosevelt administration's commitment to instituting a truly multilateral economic system for the post-war era. Put simply, where it served both the economic self-interest and the broader political goals of the US to promote multilateralism - as it did in areas like the British Empire and the Middle East - the Roosevelt administration successfully advocated such a policy. However, in a region like South America, where short-term economic interests and security concerns clashed with the broader goal of multilateralism, the US was unwilling to effectively promote this trading system. In this sense the outcome of Anglo-American negotiations concerning South America supports the earlier conclusions of revisionists that it was naked self interest that constituted the fundamental motivation behind US economic diplomacy with Britain during the Second World War. Albeit in this case the methods used to 
promote US interests were very different to those emphasised by the early revisionist scholars.

\section{Notes}

$1 \quad$ Paul Kennedy, The Rise and Fall of Great Powers: Economic Change and Military Conflict from 1500 to 2000 (London: Fontana Press, 1988), 364-5.

2 Ibid., 459-65; Randall B. Woods, 'FDR and the Triumph of American Nationalism', Presidential Studies Quarterly 19, no. 3 (1989): 569.

3 Ronald Hyam, Britain's Imperial Century, 1815-1914: A Study of Empire and Expansion, 3rd ed. (Basingstoke: Palgrave, 2002), 58-60; Sir Robert Marett, Latin America: British Trade and Investment, (London: Charles Knight \& Co., 1973), 6-7, 11.

4 Joseph Smith, Illusions of Conflict: Anglo-American Diplomacy Toward Latin America, 1865-1896, (Pittsburgh: University of Pittsburgh Press, 1979), 120-9; J. Fred Rippy, South America and Hemisphere Defense, (Louisiana: Louisiana State University Press, 1941), 47.

5 Emily S. Rosenberg, World War I and the Growth of United States Predominance in Latin America, (New York: Garland, 1987), 37-55.

$6 \quad$ Ibid., 59-65; Rippy, South America and Hemisphere Defense, 49.

7 Rippy, South America and Hemisphere Defense, 49; David Green, The Containment of Latin America: A History of the Myths and Realities of the Good Neighbor Policy (Chicago: Quadrangle Books, 1971), 19; Lloyd C. Gardner, Economic Aspects of New Deal Diplomacy, 2nd ed. (Boston: Beacon Press, 1971) [first published 1964], 51-2; Rory Miller, Britain and Latin America in the Nineteenth and Twentieth Centuries (London: Longman, 1993), 207; Marett, Latin America, 13. Winston S. Churchill, The Second World War, 6 vols (London: Cassel \& Co., 1948-1954).

9 For Churchill's concerns when writing his account of the war see David Reynolds, 'Roosevelt, Churchill, and the Wartime Anglo-American Alliance, 1939-1945: Towards a New Synthesis', in The 'Special Relationship': Anglo-American Relations since 1945, eds Roger Louis and Bull Hedley (Oxford: Clarendon Press, 1986), 17; Ritchie Ovendale, Anglo-American Relations in the Twentieth Century (Basingstoke, Macmillan Press, 1998), 39; Mark A. Stoler, Allies in War: Britain and America Against the Axis Powers, 1940-1945 (London: Hodder Arnold, 2005), xxi-xxii; David Reynolds, In Command of History: Churchill Fighting and Writing the Second World War (New York, Basic Books, 2007).

10 See, for example, H.C. Allen, Great Britain and the United States: A History of Anglo-American Relations, 1783-1952 (New York: St. Martin's Press, 1955); Herbert Feis, Churchill, Roosevelt, Stalin: The War They Waged and the Peace They Sought, 2nd ed. (Princeton: Princeton University Press, 1967) [first published 1957]; John L. Snell, Illusion and Necessity: The Diplomacy of Global War, 1939-1945 (Boston: Houghton Mifflin, 1963); Russell Buchanan, The United States and World War II (New York: Harper \& Row, 1964); Gaddis Smith, American Diplomacy during the Second World War, 1941-1945 (New York: McGraw-Hill, 1965). When Churchill did deal with AngloAmerican economic diplomacy he tended to gloss over any disagreements raised by the issue. See Churchill, The Second World War, 3: 386-8, 392-3, 397.

11 Richard Gardner, Sterling-Dollar Diplomacy: Anglo-American Collaboration in the Reconstruction of Multilateral Trade (Oxford: Clarendon Press, 1956). For more on multilateralism, see G. John Ikenberry, 'Rethinking the Origins of American Hegemony', Political Science Quarterly, 104, no.3 (1984): 382; Dick Steward, Trade and Hemisphere: The Good Neighbor Policy and Reciprocal Trade (Columbia: University of Missouri Press, 1975), 12.

12 Frederick Benham, Great Britain Under Protection (New York: Macmillan, 1941), 90-102.

13 Randall B. Woods, A Changing of the Guard (Chapel Hill: University of North Carolina Press, 1990), 18

14 For the Atlantic Charter, see Foreign Relations of the United States [hereafter FRUS], 1941, (Washington DC, USGPO, 1958), vol. 1, 367-369. For the Master Lend-Lease Agreement, see Department of State Bulletin, 28 February 1942 (Washington DC, USGPO, 1942). For the Bretton 
Woods Agreements, see Department of State Publication No. 2866: Proceedings and Documents of the United Nations Monetary and Financial Conference, Bretton Woods, New Hampshire, July 1-22, 1944 (Washington DC: USGPO, 1948).

15 Gardner, Sterling-Dollar Diplomacy, 7-16; Cordell Hull, The Memoirs of Cordell Hull, 2 vols (New York: Macmillan, 1948), 1: 81-6, 363-5. For further examples of this thesis by officials who participated in wartime diplomacy, see Herbert Feis, The Sinews of Peace (New York: Harper \& Bothers, 1944), chapter 3; E. F. Penrose, Economic Planning for Peace (Princeton New Jersey, Princeton University Press, 1953), chapter 1.

16 William Appleman Williams, The Tragedy of American Diplomacy, 3rd ed. (New York: W.W. Norton \& Co., 1972) [first published 1959], chapter 5. Further revisionist examples of Williams' 'open door' thesis include Walter LaFeber, America, Russia and the Cold War, 1945-1992, 7th ed. (New York: McGraw-Hill, 1993) [first published 1966], chapter 1; Barton J. Bernstein, 'American Foreign Policy and the Origins of the Cold War', in The Politics and Policies of the Truman Administration, ed. Barton J. Bernstein (Chicago: Quadrangle Books, 1970), 15-61; Thomas G. Paterson, 'The Quest for Peace and Prosperity: International Trade, Communism and the Marshall Plan', in Cold War Critics: Alternatives to American Foreign Policy in the Truman Years, ed. Thomas G. Paterson (Chicago: Quadrangle Books, 1971), 78-112. Kolko, The Politics of War, 242-66.

18 Gardner, Economic Aspects of New Deal Diplomacy. Kolko, The Politics of War, chapter 12; Gardner, Economic Aspects of New Deal Diplomacy, 275-88. Key works include Roger Louis, Imperialism at Bay: The United States and the Decolonization of the British Empire, 1941-1945 (Oxford: Clarendon, 1977); Christopher Thorne, Allies of a Kind: The United States, Britain, and the War against Japan, 1941-1945 (London: Hamilton, 1978); Robert M. Hathaway, Ambiguous Partnership: Britain and America, 1944-1947 (New York: Columbia University Press, 1981); David Reynolds, The Creation of the Anglo-American Alliance, 1937-1941: A Study in Competitive Cooperation (London: Europa Publications, 1981); Donald Cameron Watt, Succeeding John Bull: America in Britain's Place, 1900-1975: A Study of the Anglo-American Relationship and World Politics in the Context of British and American Foreign-Policy-making in the Twentieth Century (Cambridge: Cambridge University Press, 1984).

21 Woods, A Changing of the Guard. See also Woods, 'FDR and the Triumph of American Nationalism', 567-81; Randall B. Woods, 'FDR and the New Economic Order', in FDR's World: War, Peace, and Legacies, eds. David B. Woolner, Warren F. Kimball and David Reynolds (Basingstoke, Palgrave-Macmillan, 2008), 175-92. Alan P. Dobson, US Wartime Aid to Britain, 1940-1946 (London: Croon Helm, 1986). See also Alan P. Dobson, The Politics of the Anglo-American Economic Special Relationship, 1940-1987 (Brighton: Wheatsheaf, 1988) chapter 2.

23 See, for example, Christopher Hitchens, Blood, Class and Nostalgia: Anglo-American Ironies (London: Vintage, 1990), chapter 8; Georg Schild, Bretton Woods and Dumbarton Oaks: American Economic and Political Post-War Planning in the Summer of 1944 (New York: St. Martin's Press, 1995), 80-4; Jonathan Fenby, Alliance: The Inside Story of How Roosevelt, Stalin and Churchill Won One War and Began Another (London: Simon \& Schuster, 2006), 59-60.

24 For the US challenge to Britain in South-East Asia see Walter LaFeber, 'Roosevelt, Churchill, and Indochina, 1942-1945', American Historical Review 80, no.5 (1975): 1277-95. For the Middle East see Hitchens, Blood, Class and Nostalgia, chapter 8; Sean Dennis Cashman, America, Roosevelt, and World War II (New York: New York University Press, 1989), 341-5; John A. DeNovo, 'The Culbertson Economic Mission and Anglo-American Tensions in the Middle East, 1944-1945', Journal of American History 63, no. 4 (1977): 913-36. For North Africa, see Harold G. Marcus, Ethiopia, Great Britain and the United States, 1941-1974: The Politics of Empire (Berkeley: University of California Press, 1983); Robert Vitalis, "The "New Deal" in Egypt: The Rise of AngloAmerican Commercial Competition in World War II and the Fall of Neocolonialism', Diplomatic History 20, no. 2 (1996): 211-39.

25 The exceptions to this are a small number of studies exploring Anglo-American relations in particular South American countries during the war. See E.L. Peffer, 'Cordell Hull's Argentine Policy and Britain's Meat Supply', Inter-American Economic Affairs, 10, no. 3 (1956): 3-21; Nicholas Bowen, 
'The End of British Economic Hegemony in Argentina: Messersmith and the Eddy-Miranda Agreement', Inter-American Economic Affairs, 28, no. 4 (1975): 3-24; Nicholas Bowen, 'Britain, Argentina, and the United States, 1938-1946: Conflict and Collaboration with the Atlantic Triangle', unpublished PhD thesis, Cambridge University, 1975; Marcelo de Paiva Abreu, 'Anglo-Brazilian Economic Relations and the Consolidation of American Pre-Eminence in Brazil, 1930-1945', in Latin America, Economic Imperialism and the State: The Political Economy of the External Connection from Independence to the Present, eds Christopher Abel and Colin M. Lewis (London: Institute of Latin American Studies, 1985), 379-93. See also the author's own recent work on the topic: Thomas C. Mills, 'Anglo-American Economic Diplomacy During the Second World War and the Electrification of the Central Brazilian Railway', Diplomacy and Statecraft 20 (March 2009): 69-85; Thomas C. Mills, 'The "Hemisphere Isolationists" and Anglo-American Economic Diplomacy during the Second World War', Journal of Transatlantic Studies 9, no. 1 (2011): 63-75. Alec Campbell, 'Anglo-American Relations, 1939-1946: A British View', in Argentina Between the Great Powers, 1939-46, eds Guido di Tella and Donald Cameron Watt (Oxford: Macmillan, 1989), 117; Warren F. Kimball, “The Juggler': Franklin D. Roosevelt and Anglo-American Competition in Latin America' in Argentina Between the Great Powers, 1939-46, eds. di Tella and Watt, 18-33. Kimball's essay is expanded upon in Warren F. Kimball, The Juggler: Franklin Roosevelt as Wartime Statesman (Princeton: Princeton University Press, 1991), 107-25.

27 Laurence Duggan, The Americas: The Search for Hemisphere Security (New York: Henry Holt, 1949), 74-5.

28 Reynolds, The Creation of the Anglo-American Alliance, 272; James MacGregor Burns, Roosevelt: The Soldier of Freedom (New York: Harcourt Brace Jovanovich, 1970), 491.

29 Victor Bulmer-Thomas, British Trade with Latin America in the Nineteenth and Twentieth Centuries (London: Institute of Latin American Studies, 1998), 12; Hathaway, Ambiguous Partnership, 22. For criticisms of British censorship policy, see 'Senators Defeat Clipper Mail Curb', New York Times, 16 February 1940, 9; 'Charges British Sell Goods Given Them to Carry on War', Chicago Illinois Tribune, 1 July 1941, 1; Statement by Louis C. Rabaut (Dem.-Mich.), Congressional Record, 13 November 1941, 77th Congress, 1st Session, 8844. Regarding economic warfare see Franklin Johnston, 'How Britain's Blacklists and Censorship Affect American Traders', 3 March 1941, Export Trade and Shipper, 4; Buenos Aires to Foreign Office, 7 July 1941, Ministry of Economic Warfare Records, The National Archives of the United Kingdom, Kew, London [hereafter TNA] FO 837/198; 'Exporters Charge British Re-sales', New York Times, 6 July 1941, 1, 2. Regarding Britain's export policy see Grigsby to Campbell, 26 May 1941, Foreign Office General Correspondence TNA: FO 371/25989/A4507 [hereafter cited as TNA: FO 371 with file numbers]; Washington to Foreign Office. TNA: FO 371/25989/A5599; Washington to Foreign Office, 4 July 1941. TNA: FO 371/25989/A5384.

31 McDonald to McCabe, 26 January 1942, Disposition of Lend-Lease Materials Abroad, Box 104, General Subject File, Office of Lend-Lease Administration, Foreign Economic Administration [FEA], Record Group 169 (RG169), United States National Archives and Records Administration, College Park, Maryland [hereafter NARA].

32 'Statement by Sir John Reith in answer to question by Arthur Henderson', 4 March 1940, FO 371/25093/W3929, TNA; Overton to Leith-Ross, 7 January 1941. TNA: FO 371/28738/W390; Mather-Jackson minute, 16 June 1941, Perowne to Grubb, 25 June 1941. TNA: FO 371/25989/A4507; 'U.K. Export to S. America: A US Complaint Unjustified', Financial Times, 8 July 1941, 'United Kingdom Trade Policy in Latin America', State Department Decimal File, 610.4117/22 [hereafter cited by decimal reference], RG59, NARA; Ashton minute, 7 July 1941, Foreign Office to Washington, 12 July 1941, FO 371/25989/A5384, TNA; Washington to Foreign Office, 18 July 1941. TNA: FO 371/25989/A5601.

33 'Correspondence Respecting the Policy of His Majesty's Government in Connexion with the Use of Materials Received Under the Lend-Lease Act', Cmd. 6331, 10 September 1941, Parliamentary Papers 1940-41, vol. 3: United States No. 2 (London: HMSO, 1941). For censorship, see Memo of conversation between Moffat and Lothian, FRUS, 1939, vol. 2, 267. For blacklisting, see Foreign Office to Washington, 9 October 1941. TNA: FO 371/28752/W12610; Reading to Helm, 10 October 1941. TNA: FO 371/28752/W12610. 
British exports to South America declined from a pre-war figure of $£ 34.2$ million to just $£ 27.3$ million in 1941. This decline was most marked in those products specifically targeted by British policies, such as manufactures containing steel and iron. See Statistical Digest of the War (London: HMSO, 1951), 162, 166.

35 State Department to London, 20 January 1942, FRUS, 1942, vol. 5, 283-4; State Department to representatives in American Republics, 28 January 1942, FRUS, 1942, vol. 5, 285-6; Memo from British embassy, 26 February 1942, Memos Relating to General Latin American Affairs, Office of American Republic Affairs [OARA], Box 6, RG59, NARA; Edminster for Acheson, 26 December 1941, 621.4117/19, RG59, NARA; State Department to American Diplomatic and Consular Offices in the other American Republics, 25 March 1942, 610.4117/23A, RG59, NARA.

36 Memo by unknown for Bonsal, 14 April 1942, Memos Relating to General Latin American Affairs, OARA, Box 6, RG59, NARA.

37 'Memorandum Respecting the Anglo-United States-Brazilian Triangle' by Gallop, 15 July 1942, FO 371/30369/A6565, TNA.

38 Perowne minute, 27 February 1942. TNA: FO 371/30500/A1516.

39 Acheson, Present at the Creation, 31.

40 Acheson to American Diplomatic and Consular Offices in the other American Republics, 10 July 1942, 610.4117/30A, RG59, NARA.

41 Chapin to Duggan, 6 April 1942, 610.4117/31, RG59, NARA.

42 Dawson to State Department, 5 August 1942, 610.4117/42, RG59, NARA; Bowers to State Department, 31 July, 1942, 610.4117/40, RG59, NARA; Bliss Lane to State Department, 21 August 1942, 610.4117/44, RG59, NARA; Cross to State Department, 1 September 1942, 610.4117/48, RG59, NARA; Gallop minute, 17 November 1942. TNA: FO 371/30516/A10550; Brickell to Foreign Office, 21 October 1942, Sands untitled report, 9 December 1942. TNA: FO 371/30516/A10693; Nosworthy to Scott, 15 November 1942. TNA: FO 371/30369/A11219.

43 Butler minute, 5 September 1942. TNA: FO 371/30516/A8229; Perowne to Campbell, 31 October 1942. TNA: FO 371/30516/A8581; Washington Chancery to South American department, 9 July 1942, TNA FO 371/30516/A6602.

44 Randall B. Woods, The Roosevelt Foreign Policy Establishment and the 'Good Neighbor': The United States and Argentina, 1941-1945 (Lawrence: Regents Press, 1979), 23-4; Max Paul Freidman, Nazis and Good Neighbors: The United States Campaign Against the Germans of Latin America in World War II (Cambridge: Cambridge University Press, 2003), 78-9. Sumner Welles, The Time for Decision (London: Hamish Hamilton, 1944), 187. Grubb to Perowne, 21 January 1943. TNA: FO 371/33903/A959. Extract from letter of July 1942 from the Treasury department to Rockefeller. TNA: FO 371/33901/A3135; 'Internal Revenue Code', 1942, ‘Trade Promotion' Folder, Box 31, Subject File, Records of the Office of the Administrator, FEA, RG169, NARA. 'President of US Chamber of Commerce on "American Century", South American Journal, 26 June 1943, 338; 'The Future of Investment in Latin America', South American Journal, 11 March 1944, 150.

49 Perowne memo, 29 December 1942. TNA: FO 371/30516/A12124; Kelly to Eden, 19 February 1943. TNA: FO 371/33907/A2855; Playfair minute, 16 April 1943. TNA: FO 371/33907/A3590;

Washington to Foreign Office, 29 April 1943. TNA: FO 371/33908/A3996.

50 Campbell to Perowne, 4 September 1942, FO 371/30516/A8580, TNA; Perowne to Campbell, 31 October 1942, 'The US and Great Britain in Latin America' memo by Perowne, 29 December 1942. TNA: FO 371/30516/A12124; 'Commercial Policy in Regard to Latin America', undated. TNA: FO 371/33908/A4370; Campbell to Perowne, 4 September 1942. TNA: FO 371/30516/A8580; Perowne to Campbell, 31 October 1942. TNA: FO 371/30516/A8581; 'Future British Trade Relations with Latin America', 13 February 1943. TNA: FO 371/33907/A1710; Humphreys paper, undated [March 1943]. TNA: FO 371/33903/A2213; Playfair minute for Bewley, Rowe-Dutton, Waley, 16 April 1943. TNA: FO 371/33907/A3590.

51 Dobson, The Creation of the Economic Special Relationship, 37-8. 
'War Cabinet Lord President's Committee. Conclusions of a Meeting of the Committee held on Friday 21st May, 1943 at 10.30a.m.', 'Commercial Policy in Latin America'. TNA: FO 371/33908/A4800.

53 Aide-Memoire from British embassy in Washington, 9 July 1943, Folder 216, Box 59, Cordell Hull Papers, Cambridge University Library [CUL]; Memo of conversation, 10 July 1943, Folder 216, Box 59, Hull Papers, CUL; Washington to Foreign Office, 10 July 1943. TNA: FO 371/33909/A6498.

54 'Notes on a Visit to Washington and Ottawa' by Gallop, 14 March 1944. TNA: FO 371/35185/AS1621; Duggan, The Americas, 102; Connell-Smith, The Inter-American System, 128; 'British Activities in the Other American Republics', 30 January 1945, Box 13, Memorandums of the Division of American Republic Analysis and Liaison, OARA, RG59; Memorandum of conversation, 17 July 1944, memorandum of conversation', 23 January 1944, Folder 216, Box 59, Hull Papers, CUL; Buenos Aires to State Department, 31 March 1944, 735.41/29, RG59, NARA.

55 Friedman, Nazis and Good Neighbors, 189-90; C. C. Concanon, 'The Trade Outlook for Medicinals and Pharmaceuticals', 1 January 1940, Export Trade and Shipper, 8; Taylor, 'The Axis Replacement Program', 159.

56 Mills, 'Anglo-American Economic Diplomacy During the Second World War and the Electrification of the Central Brazilian Railway': 69-85.

57 Campbell, 'Anglo-American Relations, 1939-1946', in Argentina between the Great Powers, eds. di Tella and Watt, 15. 